\title{
Dualization, stratification, liberalization, or what? An attempt to clarify the conceptual underpinnings of the dualization debate
}

\author{
Marius Busemeyer ${ }^{1}$ and Achim Kemmerling ${ }^{2 *}$ (D) \\ ${ }^{1}$ Politik- und Verwaltungswissenschaft, Universitat Konstanz Fachbereich fur Politik- und Verwaltungswissenschaft, \\ Konstanz, Baden-Württemberg, Germany and ${ }^{2}$ Willy Brandt School of Public Policy, Universität Erfurt, Erfurt, Germany \\ *Corresponding author. Email: achim.kemmerling@uni-erfurt.de
}

(Received 6 June 2018; accepted 11 July 2018; first published online 5 November 2019)

\begin{abstract}
Despite its many contributions, a central problem in the dualization debate is conceptual overstretching, as we will argue in this short comment. The term "dualization" has been used to describe different processes, which are often subsumed under this heading: the rise of atypical employment, increasing labor market stratification in general, or the partial deregulation of welfare state policies and institutions. This multitude of usages weakens the utility of dualization as a theoretical concept. In the next section, we briefly look at the evolution of the dualization debate on the micro level before we proceed to the macro level. In the concluding section, we speculate about the future of dualization as a concept for describing welfare state transformations.
\end{abstract}

Key words: Comparative political economy; labor economics; social policy

\section{Introduction and overview}

Inspired by Rueda's original contribution (Rueda, 2005), the debate about the "dualization" of welfare states and political economies more broadly has made a number of important contributions in recent years. For instance, a central insight of scholarship in this field (Rueda, 2005; Palier and Thelen, 2010; Emmenegger et al., 2012; Schwander and Häusermann, 2013) is that more attention should be paid to differences in the distribution of labor market risk rather than to income and wealth only. Because welfare state institutions, employment protection legislation, and labor market policies affect the distribution of labor market risks, concerns about rising inequality are also related to the increasing volatility of life-courses and the precariousness of employment relationships.

Despite its many contributions, a central problem in the dualization debate is conceptual overstretching, as we will argue in this short comment. The term "dualization" has been used to describe different processes, which are often subsumed under this heading: the rise of atypical employment (in some countries), increasing labor market stratification in general (in virtually all OECD countries) as well as the partial deregulation of welfare state policies and institutions. This multitude of usages weakens the utility of dualization as a theoretical concept. Therefore, the important question is whether dualization is a term that captures the macro level of policy-making and regulation (as implied in Palier and Thelen, 2010) or is a description of labor market outcomes (as implied in Eichhorst and Marx, 2012), i.e. changing forms of labor market stratification and their political implications on the micro level. 
Labor market regulation and outcomes are certainly related to each other, but there is a tendency in the dualization literature to blur the distinction between macro-level policies and institutions of regulation, and the micro-level distribution of labor market risks. In this comment, we argue that the term should be used in a narrower, but more clearly defined manner, namely to describe trends in policy-making observed in some countries as part and parcel of a broader tendency towards liberalization and deregulation (Palier and Thelen, 2010; Emmenegger et al., 2012; Thelen, 2014; for a similar argument, see also Busemeyer, 2012 and Busemeyer and Trampusch, 2013).

There are several reasons why narrowing down the concept strengthens its value. For one, when using the concept of "dualization" to describe policy changes rather than labor market outcomes, we avoid the controversial debate about proxies for dualization on the individual level (see Marx and Picot in this volume). Another reason is that a focus on the macro level of policy changes allows us to see dualization as a consequence of larger processes such as liberalization. In the next section, we briefly look at the evolution of the dualization debate on the micro level before we proceed to the macro level. In the concluding section, we speculate about the future of dualization as a concept for describing welfare state transformations.

\section{Dualization on the micro-level? The insider-outsider divide}

The conceptual confusion surrounding the dualization concept comes in part from its disparate intellectual origins (see Introduction to this symposium). Political scientists initially employed a politico-economic notion of dualization to analyze the political implications of this insider-outsider divide. For instance, Rueda (2005: 62) defines insiders as "workers with highly protected jobs", whereas outsiders are "either unemployed or hold jobs characterized by low salaries and low levels of protection". Over time, scholars began to move away from the stark distinction between insiders and outsiders and started to work more with gradual measures of labor market risk (Rehm, 2009; Rehm et al., 2012). Such gradual measures show that the association between risk and income is not as tight as one would assume and that it varies across countries (see also Schwander and Häusermann, 2013). More recent contributions to the dualization literature have also used more fine-grained measures of employment status such as being a temporary or parttime worker (see also Picot and Marx, and Vlandas in this symposium).

One of the reasons why the micro-level literature on attitudes and preferences has evolved is that it is very difficult to assess who these groups actually are and whether a particular social policy reform privileges insiders or outsiders. Insiders often feel like outsiders because eventually even holders of stable contracts might experience job loss. To take the famous example of the Hartz reform in Germany: This reform put the brunt of adjustment on presumed outsiders (Kemmerling and Bruttel, 2006), but insiders reacted at least as strongly against the reform as outsiders did because they also felt affected or expected to be affected in the future.

Another example of the blurry conceptual boundaries between insiders and outsiders is the reform of early retirement schemes across Europe. In a number of countries, the unemployed elderly would receive support from generous early retirement schemes to bridge the gap between unemployment and entry into regular retirement (Hartlapp and Kemmerling, 2008). If these generous early retirement schemes are phased out, does this change benefit insiders or outsiders and who exactly are the insiders in this case? These brief examples show that in many ways, the insider-outsider divide is an ideal-type distinction, which is often difficult to implement in the practice of empirical analysis.

A second reason why the dichotomous distinction between labor market insiders and outsiders is problematic is that the notion of dualization as a process implies a particular kind of change over time: To be able to meaningfully speak of an "age of dualization" (Emmenegger et al., 2012) on the micro-level of policy preferences and labor market outcomes, research would need to show that the distribution of labor market risks has become more "dualistic" over time, i.e. increasing labor market risk for outsiders combined with (relatively) decreasing risk for insiders. It would also need to show that the insider-outsider divide is becoming the dominant cleavage, superimposing other 
cleavages including income and education. In reality, however, it seems more likely that labor market stratification is a multifaceted process, involving multiple cleavages and fault lines that-if anything-becomes more complex over time. In any case, scholarship in the dualization tradition would need to show that employment status has really become a more important cleavage affecting preferences and patterns of political participation than it was in the past.

A third reason to question the empirical validity of the dichotomous distinction between insiders and outsiders is to reflect on the symmetry of labor market divides. Initially, dualization theories conceptualized a division between the core workforce of large, unionized companies on the one hand and workers or employees on the periphery of internal labor markets on the other hand (Lindbeck and Snower, 2001). Unlike Rueda (2005)'s and Saint-Paul (2000)'s ideas, this earlier version of insider-ship is much closer to a model of special rather than of general interest politics (Kemmerling, 2009). Special-interest politics may account for certain problems of the insider-outsider literature. For instance, we know that for outsiders it is much harder to organize politically, given how heterogeneous they are. Hence, the lack of significant differences between insiders and outsiders in, say, stated preferences for welfare state and labor market issues (as found, for instance, by Emmenegger (2009)) may be partly driven by the fact that outsiders are a more heterogeneous and less well-organized group compared to the traditional insiders.

To sum up, a broad trend in the literature studying the implications of dualization on the micro level has been to move away from the stark distinction between insiders and outsiders as it was described in the early contributions and/or to develop more fine-grained measures of outsider-ness. This development seems empirically justified as labor market divides become increasingly complex. However, it defies the original purpose of the dualization argument, because it challenges the core argument that labor market risks are distributed in a starkly asymmetrical manner, protecting insiders to the detriment of outsiders.

\section{Dualization on the macro level of policy-making}

Another strand in the literature has studied processes of dualization on the macro level of policies and institutions. Dualization on the macro level can happen in several, related fields. The classic example is the increasing differentiation between legal or de facto employment protection for permanent and for temporary workers (Eichhorst and Marx, 2012). There is robust evidence of "institutional dualization" in the sense of increasing divergence in employment protection for different groups of employees. In such cases, we also see that these regulatory changes affect the political behavior of these two types of workers differently (Marx, 2014). However, the correspondence of macro-level institutional dualization to a similar process of dualization on the micro-level of outcomes and preferences is not always so strong. Furthermore, starting with the macro level also implies that the causal path runs from the level of policy making to the individual level of political behavior (see below).

Another form of institutional dualization happens in the form of differential coverage in social insurance schemes. The literature usually identifies Bismarckian (conservative) welfare state regimes as particularly prone to dualization (Palier and Thelen, 2010; Eichhorst and Marx, 2012): as social benefits depend on a (traditional) work history, those with higher levels of labor market risks also face higher risks of social exclusion. The dualistic nature of some welfare state programs is not a new development-indeed the distinction between residual means-tested programs for the poor on the one hand, and more generous insurance-based programs for the more affluent middle class, on the other hand, is well known. The trend has intensified in recent years and this development has likely been more pronounced in continental and Southern Europe compared to other welfare state regimes.

Macro-level dualization also affects the role of industrial partners in welfare states. The eroding base of trade unions (and, to some degree, of employers' organizations) have made these organizations structurally weaker, which might affect their overall weight in welfare state and labor market politics. Selection effects also mean that some types of (large) companies will survive whereas other 
companies will disappear. This, in turn, will have dualizing effects for the coverage of the employees in terms of social security systems and employment protection (Kemmerling, 2014).

In all these cases it is important to see dualization in the context of a general liberalization process. Let us define liberalization as a process of increasing the importance of market mechanisms relative to (state) regulation, both within the welfare state and in the labor market itself. To speculate about the causes of this liberalization trend is beyond the scope of this short comment, but the evidence is mounting that economic internationalization has increasingly become an important constraint for policy-makers (Busemeyer, 2009).

In this respect, Thelen's (2014) contribution to the debate also sketches a different conception of the role of social democrats and unions. In Rueda's (2005) original work, social democratic government parties-catering to insider-oriented unions and labor market insiders-actively promote insider-oriented policies to the detriment of outsiders. Recent policy developments in the Scandinavian countries have shown that where unions continue to be powerful and encompassing, liberalizing welfare state reforms have had a more solidaristic flavor (Thelen, 2014). More importantly, it is doubtful whether social democratic parties and unions should be regarded as first movers. They might simply be forced to respond to changing circumstances by having to choose between two evils: reform and decline. The politics of dualization might be a good example of politics in hard times, where second-best solutions abound. Organized interests (unions and traditional left parties) would still prefer to live in the stable world of a Keynesian welfare state with strongly regulated labor markets, and would still prefer to mobilize outsiders. But if they must give in, they might try to defend their core clientele first before catering to the demands and interests of other segments of the workforce.

\section{Outlook into the future: dualization in the long run?}

To sum up our core argument: In our view, a perennial problem in the dualization debate is conceptual overstretching, which is a consequence of the fact that the term dualization has been applied to describe different processes at the micro-level of preferences and outcomes as well as at the macro-level of institutional change. We believe that the notion of dualization is more powerful and convincing when used to describe macro-level processes of institutional change. This is because labor market structures have become more complex over time, contributing to the formation of multiple socio-economic and political cleavages, which interact with each other to create a much more differentiated politico-economic landscape than the simple dichotomy between insiders and outsiders suggests. Hence, we have argued in favor of going back to a narrower conception of dualization, which will be helpful to understand the consequences of the institutional change on the micro level.

In closing, we want to comment briefly on the political origins of dualization at the macro level. As briefly mentioned above, the dualization of welfare state and labor market policies should be regarded as an integral part of a general trend towards liberalization, which cuts across many OECD countries (Streeck, 2009; Thelen, 2014). In this sense, dualization seems more the result of policy "drift" (Hacker, 2004) or institutional erosion (Busemeyer and Trampusch, 2013) rather than a deliberate strategy. From our perspective, although this is more of a working hypothesis rather than a clear-cut finding, the causal chain begins with liberalization pressures-as well as other factors such as increasing individualization or technological change-contributing to dualization of welfare state policies and institutions, which in turn affects labor market stratification in complex ways.

If this narrative is correct, it will have important implications in the long run, which are different from the original dualization argument. If labor market institutions indeed created stark, dichotomous divides between clearly identifiable insiders and outsiders, there might be significant potential for counter-mobilization. The unemployed and precariously employed could organize, engage in coalition building with other segments of the labor market and change the status quo of existing policies or institutions. Established parties would then start to cater 
more to the interests of outsiders (e.g., Lindvall and Rueda, 2014). New parties would arise representing new electoral coalitions (see Häusermann in this symposium).

If, however, labor market divides are not as dichotomous as expected and cross-cutting rather than reinforcing cleavages abound, the likelihood that those most affected by dualizing welfare state and labor market policies will indeed mobilize is low. Rather, those experiencing the highest degrees of labor market risk are often those with limited political influence. Increasing labor market inequalities might reinforce this trend so that different kinds of privileged "insiders" become even more influential in setting the priorities of policy-making in the future. Furthermore, social democratic and other left-wing parties as well as trade unions are reacting to liberalization rather than actively promoting dualization.

\section{References}

Busemeyer MR (2009) From myth to reality: globalization and public spending in OECD countries revisited. European Journal of Political Research 48, 455-482.

Busemeyer MR (2012) Business as a pivotal actor in the politics of training reform: insights from the case of Germany. British Journal of Industrial Relations 50, 690-713.

Busemeyer MR and Trampusch C (2013) Liberalization by exhaustion: transformative change in the German welfare state and vocational training system. Zeitschrift für Sozialreform 59, 291-312.

Eichhorst W and Marx P (2012) Whatever works: dualization and the service economy in Bismarckian welfare states. In Emmenegger P, Häusermann S, Palier B and Seeleib-Kaiser M (eds), The Age of Dualization: The Changing Face of Inequality in Deindustrializing Societies. Oxford, New York: Oxford University Press, pp. 73-99.

Emmenegger P (2009) Barriers to entry: insider/outsider politics and the political determinants of job security regulations. Journal of European Social Policy 19(2), 131-146.

Emmenegger P, Häusermann S, Palier B and Seeleib-Kaiser M (2012) How we grow unequal. In Emmenegger P, Häusermann S, Palier B and Seeleib-Kaiser M (eds), The Age of Dualization: The Changing Face of Inequality in Deindustrializing Societies. Oxford, New York: Oxford University Press, pp. 3-26.

Hacker JS (2004) Privatizing risk without privatizing the welfare state: the hidden politics of social policy retrenchment in the United States. American Political Science Review 98, 243-260.

Hartlapp M and Kemmerling A (2008) When a solution becomes the problem: the causes for policy reversal of early exit from the labour force. Journal of European Social Policy 18, 366-379.

Kemmerling A (2009) Taxing the Working Poor. The Political Origins and Economic Consequences of Taxing Low Wages. Cheltenham: Edward Elgar.

Kemmerling A (2014) How labour ended up taxing itself. The long-term evolution of the politics in German labour taxation. Journal of European Social Policy 24, 150-163.

Kemmerling A and Bruttel O (2006) New politics' in German labour market policy? The implications of the recent Hartz reforms for the German welfare state. West European Politics 29, 90-112.

Lindbeck A and Snower DJ (2001) Insiders versus outsiders. Journal of Economic Perspectives 15, 165-188.

Lindvall J and Rueda D (2014) The insider-outsider dilemma. British Journal of Political Science 44, 460-475.

Marx P (2014) The effect of job insecurity and employability on preferences for redistribution in Western Europe. Journal of European Social Policy 24(4), 351-366.

Palier B and Thelen K (2010) Institutionalizing dualism: complementarities and change in France and Germany. Politics \& Society 38, 119-148.

Rehm P (2009) Risk and redistribution: an individual-level analysis. Comparative Political Studies 42, 855-881.

Rehm P, Hacker JS and Schlesinger M (2012) Insecure alliances: risk, inequality, and support for the welfare state. American Political Science Review 106, 386-406.

Rueda D (2005) Insider-outsider politics in industrialized democracies: the challenge to social democratic parties. American Political Science Review 99, 61-74.

Saint-Paul G (2000) The Political Economy of Labour Market Institutions. Oxford: Oxford University Press.

Schwander H and Häusermann S (2013) Who is in and who is out? A risk-based conception of insiders and outsiders. Journal of European Social Policy 23, 248-269.

Streeck W (2009) Re-Forming Capitalism: Institutional Change in the German Political Economy. Oxford, New York: Oxford University Press.

Thelen K (2014) Varieties of Liberalization and the new Politics of Social Solidarity. Cambridge, New York: Cambridge University Press.

Cite this article: Busemeyer M, Kemmerling A (2020). Dualization, stratification, liberalization, or what? An attempt to clarify the conceptual underpinnings of the dualization debate. Political Science Research and Methods 8, 375-379.

https://doi.org/10.1017/psrm.2019.47 